May 16th, 11:30 AM

\title{
Risk Structured Model of Cholera Infections In Cameroon
}

Fnu Eric Ngang Che

Howard University, ericngangche@yahoo.com

Abdul-Aziz Yakubu Dr.

Howard University, ayakubu@howard.edu

Follow this and additional works at: https://scholarscompass.vcu.edu/bamm

Part of the Life Sciences Commons, Medicine and Health Sciences Commons, and the Physical Sciences and Mathematics Commons

https://scholarscompass.vcu.edu/bamm/2019/thur/3

This Event is brought to you for free and open access by the Dept. of Mathematics and Applied Mathematics at VCU Scholars Compass. It has been accepted for inclusion in Biology and Medicine Through Mathematics Conference by an authorized administrator of VCU Scholars Compass. For more information, please contact libcompass@vcu.edu. 


\begin{abstract}
FOR 2019 BAMM MEETING
Title: Risk Structured Model of Cholera Infections In Cameroon

In this talk, we will introduce a high and low risk structured model of cholera infection dynamics in Cameroon. The model has direct (human-to-human) transmission and indirect (contaminated water-to-human) transmission. We will use our model's demographic equation to 'fit' the population of Cameroon, and then use the fitted cholera model to capture cholera cases in Cameroon from 1987 to 2017. Furthermore, we will use our model to study the impact of various cholera control strategies on the number of cholera infections in Cameroon.
\end{abstract}

